\title{
RESPONSE OF HAART (HIGHLY ACTIVE ANTIRETROVIRAL THERAPY) ON CD4 COUNTS AND HAEMOGLOBIN IN PATIENTS WHO ACQUIRED HIV INFECTION BY HETEROSEXUAL AND BLOOD TRANSFUSION ROUTES
}

\author{
Ravichandran Narayanan1, Raja Krishnaraj², Kumar Satagopan³, S. Vijila, AmalaSharmila Irudayaraj5 \\ ${ }^{1}$ Assistant Professor, Department of General Medicine, Stanley Medical College, Chennai. \\ ${ }^{2}$ Assistant Professor, Department of General Medicine, Stanley Medical College, Chennai. \\ ${ }^{3}$ Assistant Professor, Department of Pulmonology, Government Hospital of Thoracic Medicine, Chennai. \\ ${ }^{4}$ Senior ART Medical officer, ART Centre, Government Hospital of Thoracic Medicine, Chennai. \\ ${ }^{5}$ Bio-Statistician, ART Centre, Government Hospital of Thoracic Medicine, Chennai.
}

\section{ABSTRACT}

\section{BACKGROUND}

Dynamics of HIV acquired through the blood transfusion is studied largely, there are no studies that show the difference of impact of HAART on HIV acquired by heterosexual and blood transfusion routes. This study compares the impact of HAART between these groups.

\section{MATERIALS AND METHODS}

It is a descriptive comparative study. Data of HIV patients was collected from records and observed for eight years period. 39 PLHA who acquired HIV by blood transfusion and were alive on HAART as on December 2012 were matched with 39 patients who acquired HIV by heterosexual route with age, sex and duration of ART were analysed. Data was analysed with CD4 raise and HB raise in both groups.

\section{RESULTS}

Total cases were 78. 39 patients who acquired HIV by transfusion and heterosexual route in each group were selected. 23 males and 16 females acquired HIV by transfusion route. 24 males and 15 females acquired HIV by heterosexual route. Mean age of both groups is 32.06 years. Mean duration of ART was 6.6 years for both groups. The mean raise in CD4 between two groups heterosexual and blood-transfusion was 440 and 544 respectively. The mean raise in HB between two groups heterosexual and blood-transfusion was $1.6 \mathrm{~g} \%$ and $2.6 \mathrm{~g} \%$ respectively. The CD4 raise was 20\% more in transfusion-acquired HIV without statistical significance. The haemoglobin raise in transfusion-acquired HIV was $60 \%$ more than without statistical significance. Unpaired t-tests show females in transfusion group have statistically significant raise in HB. Unpaired t-tests show males in heterosexual group have statistically significant poor raise in CD4.

\section{CONCLUSION}

Response to HAART by patients who acquired HIV by blood transfusion was better than the patients who acquired HIV by heterosexual route. Differences in early stages of acute HIV infection and the differences in involvement of lymphatic tissues and reservoirs in transfusion-acquired HIV may be the reasons for better response to HAART.

\section{KEYWORDS}

Blood Transfusion, HAART, CD4, Haemoglobin, Heterosexual Route.

HOW TO CITE THIS ARTICLE: Narayanan R, Krishnaraj R, Satagopan K, et al. Response of HAART (highly active antiretroviral therapy) on CD4 counts and haemoglobin in patients who acquired HIV infection by heterosexual and blood transfusion routes. J. Evolution Med. Dent. Sci. 2017;6(53):4025-4029, DOI: 10.14260/Jemds/2017/870

\section{BACKGROUND}

Highly Active Anti-retroviral therapy (HAART) remains the mainstay of treating patients living with HIV and AIDS (PLHA). The multidrug therapy is the choice of treatment for the infection. The response to the multidrug therapy is proved beyond doubt and superior to the monotherapy.

The response to HAART depends on various factors like gender, age at which HIV was diagnosed, route of HIV

Financial or Other, Competing Interest: None.

Submission 08-05-2017, Peer Review 22-06-2017,

Acceptance 27-06-2017, Published 03-07-2017.

Corresponding Author:

Dr. Raja Krishnaraj,

Assistant Professor,

Department of General Medicine,

Stanley Medical College,

Chennai- 600001.

E-mail: krajadr@hotmail.com

DOI: $10.14260 /$ jemds $/ 2017 / 870$ infection, CD4 cell count when HIV was diagnosed, CD4 cell count, haemoglobin levels and viral load at initiation of HAART.(1) Dynamics of HAART in HIV with Tuberculosis, HBV and HCV co-infection, homosexuality, heterosexuality, IV drug abuse, blood transfusion, infants, children, old age patients, pregnant women and commercial sex workers varies with each association and is highly complicated.

Various studies were done to study the responses in different special situations in PLHA on HAART. The response of old age patients to HAART showed no difference in increase in CD4 count and viral load suppression.(2) In patients with HIV and HBV and HCV co-infection, the mortality was highest for HCV co-infection. Triple coinfection of HIV, HBV and HCV in 8 years followup on HAART(3) also showed very high mortality. The mortality was three times more in patients with HIV HBV co-infection than in patients with HIV infection alone.(4) In IV substance abuse 
patients without any co-infection, the outcome of HAART is similar to non-IV abusers. (5)

There were no studies to analyse the response of HAART on patients who acquired HIV by blood transfusion. In studies(6) where a natural history of HIV progression was studied 84 infections who were blood recipients, all died 34 months after the onset, with the death-strength as 182.05/100 person-years and the survival was 4 months when no HAART was given. In another study among haemophiliacs ${ }^{(7)}$ with HIV on HAART, the impact was positive in increase in CD4 count and viral suppression.

This study in a tertiary care centre will help in analysing the difference in response between heterosexual route and transfusion route acquiring PLHA on HAART.

\section{MATERIALS AND METHODS}

It was a descriptive comparative study with data as on December 2012. Data of PLHA was collected from records of patients from April 2004 to December 2012 for a period of eight years. CD4 and haemoglobin levels were tabulated every six months for eight years.

Case inclusion criteria: 862 PLHA on HAART had acquired HIV by blood transfusion as per data on April 2004. After removing deaths, lost to followup and "transferred out" to other centres only 39 PLHA who were alive and on HAART as on December 2012 were selected. These 39 transfusionacquired PLHA cases were matched with 39 PLHA who acquired HIV by heterosexual route and alive on HAART as on December 2012 with age, sex, with mean baseline CD4 counts; mean baseline haemoglobin and duration of HAART in the same period were selected for the study.

The response for the HAART was tabulated from the records with mean $\mathrm{CD} 4$ raise and mean $\mathrm{HB}$ raise, initial and final CD4 and HB from April 2004 to December 2012.

Ethical issues: Data were collected from electronic records. No individual names and personal data were collected.
Statistical methods: Basic demographic variables like sex, mean age, mean initial CD4 and mean initial HB for both groups were matched and studied with confidence intervals and pair wise comparison of means in transfusion and heterosexual routes with $\mathrm{p}$ values. Mean of final CD4 count and mean levels of final haemoglobin were studied with confidence intervals. Mean of increase of CD4 count and mean increase of final haemoglobin were studied with confidence intervals. Multivariate logistic regression with Odds ratio for variables like sex, raise in CD4 and raise in HB of HAART were used to analyse the association between the two groups. Unpaired t-tests with null hypothesis were used to associate the mean raise in CD4 and mean raise in haemoglobin levels between transfusion and heterosexual groups and males and females in both the study groups.

\section{RESULTS}

Table - 1 shows the basic demography, mean initial CD4, mean initial haemoglobin levels and duration of HAART.

Table - 2 shows the mean of final CD4, mean final haemoglobin levels of two groups in eight years' followup.

Table -3 shows the raise of mean CD4 count and mean haemoglobin levels for both the groups in eight years.

Table -4 shows means of raise in CD4 count and raise in haemoglobin levels between two groups and gender.

Table - 5 shows the association of sex, CD4 raise and haemoglobin raise between the two groups with multivariant logistic regression and Odds ratio with P-values.

Unpaired $t$ - test showed the mean CD4 raise in males with HIV due to heterogeneous route transmission was lower than the mean CD4 raise in males due to HIV acquired by blood transfusion with statistical significance of 0.002 . Unpaired $t$ - test revealed the Haemoglobin raise in females with HIV due to blood transfusion is higher than mean haemoglobin raise in HIV due to heterogeneous route transmission with statistical significance of 0.05 . Other sample mean tests had no statistical significance.

\begin{tabular}{|c|c|c|c|c|}
\hline Index & Sex & $\begin{array}{l}\text { HIV Acquired by } \\
\text { Transfusion mode }\end{array}$ & \begin{tabular}{|c|} 
HIV Acquired by \\
Heterogeneous mode
\end{tabular} & P Value \\
\hline \multirow{3}{*}{ Number of cases } & Male & 23 & 24 & 0.81 \\
\hline & Female & 16 & 15 & 0.81 \\
\hline & Total & 39 & 39 & 0.81 \\
\hline \multirow{2}{*}{ Age of patients in years (CI) } & Male & $34.82(30.5,39.1)$ & $35.04(30.9,39.1)$ & 0.94 \\
\hline & Female & $27.93(21.8,34.0)$ & $27.46(20.7,34.1)$ & 0.91 \\
\hline \multirow{3}{*}{ Mean Initial CD4 count per $\mathrm{cm}^{3}(\mathrm{CI})$} & Male & $172.9(106.5,239.3)$ & $174.5(79.7,269.2)$ & 0.97 \\
\hline & Female & $268.3(137.0,399.7)$ & $244.0(158.0,330.1)$ & 0.76 \\
\hline & All patients & $212.07(134.0,268.4)$ & $201.2(144.7,279.3)$ & 0.82 \\
\hline \multirow{3}{*}{ Mean initial HB in g\%(CI) } & Male & $11.8(10.8,12.8)$ & $11.8(11.0,12.7)$ & 0.96 \\
\hline & Female & $9.4(8.1,10.6)$ & $10.8(10.1,11.5)$ & 0.06 \\
\hline & All patients & $10.8(9.9,11.7)$ & $11.4(10.8,12.0)$ & 0.23 \\
\hline \multirow{3}{*}{ Duration of ART in years (CI) } & Male & $5.4(4.8,6.0)$ & $6.3(5.6,7.0)$ & 0.05 \\
\hline & Female & $6.2(5.4,7.1)$ & $6.2(5.7,6.8)$ & 0.95 \\
\hline & All patients & $5.7(5.2,6.3)$ & $6.3(5.8,6.7)$ & 0.12 \\
\hline
\end{tabular}




\begin{tabular}{|c|c|c|c|c|}
\hline Index & Sex & $\begin{array}{l}\text { HIV Acquired by Transfusion Mode } \\
\text { (CI) }\end{array}$ & $\begin{array}{c}\text { HIV Acquired by Heterogeneous } \\
\text { Mode(CI) }\end{array}$ & $P$ value \\
\hline \multirow{3}{*}{$\begin{array}{l}\text { Mean Final CD } 4 \text { count per } \\
\text { cubic } \mathrm{cm} .\end{array}$} & Male & $746.1(565.2,927.0)$ & $533.3(398.5,668.1)$ & 0.065 \\
\hline & Female & $771.8(573.7,969.8)$ & $814.9(601.1,1028.6)$ & 0.77 \\
\hline & All patients & $756.6(624.2,889.1)$ & $641.6(518.3,764.9)$ & 0.2 \\
\hline \multirow{3}{*}{ Mean final HB (g\%) } & Male & $14.2(13.5,14.9)$ & $13.6(13.1,14.2)$ & 0.18 \\
\hline & Female & $12.4(11.7,13.1)$ & $12.2(11.5,12.9)$ & 0.68 \\
\hline & All patients & $13.5(12.9,14.0)$ & $13.1(12.6,13.5)$ & 0.3 \\
\hline
\end{tabular}

\begin{tabular}{|c|c|c|}
\hline Index & $\begin{array}{c}\text { Mode of } \\
\text { Transmission }\end{array}$ & Mean (CI) \\
\hline \multirow{4}{*}{$\begin{array}{c}\text { Mean CD4 } \\
\text { raise }\end{array}$} & Overall & $\begin{array}{c}492.5(406.7, \\
578.2)\end{array}$ \\
\cline { 2 - 3 } & $\begin{array}{c}\text { HIV acquired by } \\
\text { transfusion mode }\end{array}$ & $\begin{array}{c}544.6 \\
(413.6,675.5)\end{array}$ \\
\cline { 2 - 3 } & $\begin{array}{c}\text { HIV acquired by } \\
\text { heterogenous mode }\end{array}$ & $\begin{array}{c}440.3 \\
(330.4,550.3)\end{array}$ \\
\hline \multirow{4}{*}{$\begin{array}{c}\text { Mean Raise in HB } \\
\text { (gms\%) }\end{array}$} & $\begin{array}{c}\text { Overall } \\
\text { HIV acquired by } \\
\text { transfusion mode }\end{array}$ & $2.1(1.6,2.6)$ \\
\cline { 2 - 3 } & $\begin{array}{c}\text { HIV acquired by } \\
\text { heterogenous mode }\end{array}$ & $1.6(1.8,3.4)$ \\
\hline \multirow{2}{*}{$\begin{array}{c}\text { Table 3. Raise of Mean CD4 Count and Mean HB Levels with } \\
\text { Confidence Intervals (CI) }\end{array}$} \\
\hline \multicolumn{2}{|c|}{} \\
\hline
\end{tabular}

\begin{tabular}{|c|c|c|c|c|c|}
\hline Index & Mean & Std. error & \multicolumn{2}{|c|}{$\begin{array}{c}\text { [95\% Conf. } \\
\text { Interval }\end{array}$} & $\begin{array}{c}\text { P- } \\
\text { value }\end{array}$ \\
\hline $\begin{array}{c}\text { Heterosexual/ } \\
\text { Female }\end{array}$ & 570.8667 & 121.9807 & 327.9721 & 813.7612 & 0.66 \\
\hline $\begin{array}{c}\text { Heterosexual/ } \\
\text { male }\end{array}$ & 358.8333 & 42.05262 & 275.0959 & 442.5708 & 0.03 \\
\hline $\begin{array}{c}\text { Transfusion/ } \\
\text { female }\end{array}$ & 503.4375 & 95.45051 & 313.3713 & 693.5037 & 0.66 \\
\hline $\begin{array}{c}\text { Transfusion/ } \\
\text { male }\end{array}$ & 573.2609 & 90.8516 & 392.3522 & 754.1695 & 0.03 \\
\hline \multicolumn{5}{|c|}{ HB Difference } \\
\hline $\begin{array}{c}\text { Heterosexual/ } \\
\text { Female }\end{array}$ & 1.386667 & 0.491922 & 0.407125 & 2.366209 & 0.03 \\
\hline $\begin{array}{c}\text { Heterosexual/ } \\
\text { male }\end{array}$ & 1.791667 & 0.418846 & 0.957638 & 2.625695 & 0.4 \\
\hline $\begin{array}{c}\text { Transfusion/ } \\
\text { female }\end{array}$ & 3.01875 & 0.526879 & 1.9696 & 4.0679 & 0.03 \\
\hline $\begin{array}{c}\text { Transfusion/ } \\
\text { male }\end{array}$ & 2.395652 & 0.596282 & 1.208303 & 3.583002 & 0.4 \\
\hline
\end{tabular}

Table 4. Means for CD4 Raise and HB Raise in Transfusion and Heterosexual Transmission and Gender

\begin{tabular}{|c|c|c|c|c|c|}
\hline Index & $\begin{array}{c}\text { Odds } \\
\text { Ratio }\end{array}$ & Std. Err. & $\mathbf{z}$ & $\mathbf{P}>|\mathbf{z}|$ & $\begin{array}{c}\text { 95\% Conf. } \\
\text { Interval }\end{array}$ \\
\hline Sex & 0.85 & 0.412 & -0.33 & 0.74 & $0.32,2.19$ \\
\hline CD4 raise & 3.49 & 4.17 & 1.05 & 0.29 & $0.33,36.31$ \\
\hline HB raise & 1.23 & 0.772 & 0.33 & 0.73 & $0.36,4.2$ \\
\hline $\begin{array}{r}\text { Table 5. Multivariate Logistic Regression with Odds Ratio } \\
\text { for Transfusion and Heterosexual Transmission }\end{array}$ \\
\hline
\end{tabular}

\section{DISCUSSION}

The risk of HIV transfusion through unscreened blood products is $90 \% .{ }^{(8)}$ Irrespective of age, gender of the recipient, the reason for transfusion and the type of component transfused, the transmission of HIV is $100 \%$ if the donor is positive for HIV infection. Longer the duration of storage of blood, lesser the transmission of HIV. The rate of progression of HIV disease is similar to other routes. Mean time for HIV infection to progress to AIDS is 8.2 years ${ }^{(9)}$ in adults without HAART. At least $25 \%$ of these patients develop AIDS in 5 years. There is no case of HIV transmitted by immunoglobulin transfusion.(10) Clotting Factor Concentrates used in haemophiliacs transmitted HIV in $80 \%$ of treated haemophilia A patients and $50 \%$ of treated haemophilia B patients.(11) Very low incidence of HIV reported in transplant patients. Artificial insemination can transmit HIV but incidence is very low.

The percentage of HIV infected persons through the blood products is $1 \%$ as per National AIDS Control Program(12) annual report 2011 to 2012. In this study period beginning from 2004 out of total HIV detected patients of 28471 cases, HIV acquired by blood transfusion was 427 about $1.4 \%$. Out of these cases, 99 were started on HAART. After followup of eight years, 39 were alive on HAART. It is low when comparing the national data of $76 \%$ alive on HAART. If transferred out data is added (after adding it is 71\%), patients alive on HAART is comparable in HIV patients acquired by transfusion in this study. The death percentage of the country during the study period was $15 \%$. In this study, we have $13 \%$ deaths of HIV patients who acquired HIV by transfusion. The incidence and death rate of HIV acquired by transfusion is comparable to national data. So the cases were matched with mean age, sex, mean baseline CD4 counts; mean baseline haemoglobin and duration of HAART to avoid bias.

All the patients in the study were started with the national ART program regimens.(13) The basic regimens were two nucleotide reverse transcriptor inhibitors (NRTI) and one non-nucleotide reverse transcriptor inhibitors (NNRTI). If haemoglobin was more than 9 gms\%, Zidovudine based regimens was started. If less than $9 \mathrm{gms} \%$, Stavudine based regimen was used. If tuberculosis was detected, the NNRTI Efavirenz was used. If Zidovudine induced anaemia occurs, the NRTI used was Stavudine. Lamivudine was the back bone in all the regimens.

The CD4 count rose significantly in all the cases irrespective of route of transmission. The mean raise in all patients was CD 4 count is 492 cells per $\mathrm{cm}^{3}$ in eight years. The mean raise in CD4 count in transfusion route was 544 cells per $\mathrm{cm}^{3}$ in eight years. The mean raise in CD4 count in heterosexual route was 440 cells per $\mathrm{cm}^{3}$ in eight years which was very significant. The raise of mean CD4 count in transfusion route was $20 \%$ more than that of the heterosexual route.

The haemoglobin levels also rose significantly in all the cases irrespective of route of transmission. The mean raise in haemoglobin level in all patients was 2.1 gms percentage in eight years. The mean raise in haemoglobin levels in transfusion route was $2.6 \mathrm{gms} \%$ in eight years. The mean raise in haemoglobin levels in heterosexual route was 1.6 gms\%in eight years. The raise of mean haemoglobin levels in transfusion route was $60 \%$ more than that of the heterosexual route. 
On comparing the CD4 and haemoglobin levels, the overall response to HAART is better in patients who acquired HIV by transfusion.

In gender wise analyses of HAART response in transfusion, we see the mean CD4 count raise of 544 cells per $\mathrm{cm}^{3}$. The raise is almost equal in both genders (male 573, female $503 \mathrm{CD} 4$ cells per $\mathrm{cm}^{3}$ ). In heterosexual group, we see females have significant raise in CD4 cell count than the males (male 358, female $570 \mathrm{CD} 4$ cells per $\mathrm{cm}^{3}$ ). In India the incidence of HIV in females occur in younger age than their male partners. Females detected with HIV disease earlier than males was due to family screening. So the females are started HAART earlier than the males. These factors may be the reasons for the better response of HAART in females in heterosexual group. In transfusion group, these differences in early detection and early start of HAART are not there because both have same chances of detection. So the response appears equal in both genders.

In gender wise analyses of HAART response in transfusion, we see that in both females and males in transfusion the haemoglobin levels raise. The raise is almost equal in both genders in transfusion group (Male 2.3, female 3.0 gms haemoglobin percentage). In heterosexual group, we see both males and females have moderate raise in haemoglobin (male 1.7, female 1.3 gms percentage). In India, the incidence of anaemia in females is more than the males. So, the females with HIV on HAART have low haemoglobin raise. The transfusion group had more raise in haemoglobin levels than the heterosexual group and almost equal in both genders.

Multivariate logistic regression of raise in CD4 count, haemoglobin and sex between the transfusion and heterosexual groups, the association of raise in haemoglobin levels is not statistically significant with transfusion ( $p$-value 0.73). Odds of raise of haemoglobin levels were 1.2 times more in transfusion group. Odds of increase in CD4 count was 3.2 times more in blood transfusion than in heterosexual route without statistical significance (0.33).

The pathogenesis of HIV can play an important role in the response to HAART. The CD4 cell and the presence of coreceptor CCR5 (14) and CXCR4 play an important role in HIV infection. The binding of virus to these receptors results in conformational changes and the viral genome enters the cytoplasm of CD4 cells. The RNA is converted to DNA by reverse transcriptase enzyme. DNA is integrated into host DNA by integrase. The viral components are formed by the CD4 cells and the virus is released by budding.

Acute HIV infection results in acute febrile illness. During the infection, the virus multiplies in lymphoid tissues, central nervous system and in other sites. High viral load is seen in plasma and lymphoid tissues. The cytotoxic T cells CD8+ cells(15) are the cells that help in killing the viruses. After several months, the viral replication reaches a steady level. The viral replication occurs in the CD4 cells whereas all other cells affected with HIV virus act as reservoirs. In transfusion, the natural sequences of events of the acute infection is altered. The infected blood products enter the blood stream and gets lodged into lymphatic cells and other sites. The early phase of the infection and multiplication and acute febrile illness is short. So, the viral load of the blood products will determine the dissemination of the virus without the replication phase in lymph nodes and reaches target organs directly. So the reservoir multiplication and priming of memory $\mathrm{T}$ cell component of the virus may be lesser in transfusion HIV than the HIV by heterosexual route. This may result in better response of HAART in transfusion group when comparing the heterosexual route. Longer the storage period lesser the viral load also may determine the infectivity.

The response of HAART in transfusion-acquired HIV was better than that of HIV acquired by heterosexual route. There is significant raise of mean CD4 count and mean raise of haemoglobin levels in transfusion-acquired HIV. The viral load of the blood donor (in window period) and the changes in the early stages of acute HIV infection and reservoir components and priming of memory $\mathrm{T}$ cells in lymph nodes in transfusion-acquired HIV may play an important role in the better response of HAART. More studies are needed to substantiate this finding.

\section{CONCLUSION}

Response to HAART by patients who acquired HIV by blood transfusion was better than the patients who acquired HIV by heterosexual route. Differences in the early stages of acute HIV infection and differences in involvement of lymphatic tissues and reservoirs in transfusion-acquired HIV may be the reasons for the better response of HAART.

\section{ACKNOWLEDGEMENT}

We acknowledge all the staff of ART centre and all the patients who made this study possible.

\section{REFERENCES}

[1] Deng L, Liu Z, Zhang S, et al. Survival time and related influencing factors of AIDS patients in Liangshan prefecture, Sichuan province, during 2008-2013. Zhonghua Liu Xing Bing Xue Za Zhi 2015;36(6):56975.

[2] Szadkowski L, Tseng A, Walmsley SL, et al. Short communication: effects of age on virologic suppression and CD4 cell response in HIV-positive patients initiating combination antiretroviral therapy. AIDS Res Hum Retroviruses 2012;28(12):1579-83.

[3] Chen M, Wong WW, Law MG, et al. Hepatitis B and C co-infection in HIV patients from the TREAT Asia HIV observational database: analysis of risk factors and survival. PLoS One 2016;11(3):e0150512.

[4] Velen K, Charalambous S, Innes C, et al. Chronic hepatitis B increases mortality and complexity among HIV-coinfected patients in South Africa: a cohort study. HIV Med 2016;17(9):702-7.

[5] Walsh N, Mijch A, Watson K, et al. HIV treatment outcomes among people who inject drugs in Victoria, Australia. BMC Infect Dis 2014;14:707.

[6] Chen SL, Zhao HR, Zhang YQ, et al. A retrospective cohort study on the natural history of AIDS caused by blood transfusion. Zhonghua Liu Xing Bing Xue Za Zhi 2012;33(7):658-62. 
[7] Dai ZS, Zhang XX, Wang JR, et al. Clinical impacts of highly active antiretroviral therapy on patients of hemophilia combined with acquired immunodeficiency syndrome: 6-year follow-up of 39 cases. Zhonghua Yi Xue Za Zhi 2009;89(13):872-5.

[8] Donegan E, Lee H, Operskalski EA, et al. Transfusion transmission of retroviruses: human T-lymphotropic virus types I and II compared with human immunodeficiency virus type 1. Transfusion 1994;34(6):478-83.

[9] Medley GF, Anderson RM, Cox DR, et al. Incubation period of AIDS in patients infected via blood transfusion. Nature 1987;328(6132):719-21.

[10] Sugg U, Schneider W, Kaufmann R, et al. Safety of immunoglobulin preparations with respect to transmission of human immunodeficiency virus. Transfusion 1987;27(1):115.
[11] Ragni MV, Winkelstein A, Kingsley L, et al. 1986 update of HIV seroprevalence, seroconversion, AIDS incidence, and immunologic correlates of HIV infection in patients with hemophilia A and B. Blood 1987;70(3):786-90.

[12] Annual report 2011-2012. Department of AIDS control, National AIDS Control Organisation, Ministry of health \& family welfare, Government of India. http://www.naco.gov.in/upload/Publication/Annual \%20Report/NACO_AR_Eng\%202011-12.pdf2016.

[13] NACO. Operational guidelines for first line ART program. Ministry of health and family welfare 2008.

[14] Samson M, Libert F, Doranz BJ, et al. Resistance to HIV-1 infection in Caucasian individuals bearing mutant alleles of the CCR-5 chemokine receptor gene. Nature 1996;382(6593):722-5.

[15] Koup RA, Safrit JT, Cao Y, et al. Temporal association of cellular immune responses with the initial control of viremia in primary human immunodeficiency virus type 1 syndrome. J Virol 1994;68(7):4650-5. 